\title{
KÖZMŰVELŐDÉSI ÉS KÖZÖSSÉGSZERVEZÉSI JÓ GYAKORLATOK A BARANYA MEGYEI KÖZSÉGEKBEN
}

\section{Absztrakt}

Kutatócsoportunk 2019 szeptembere és 2020 augusztusa között a Nemzeti Művelődési Intézet Közművelődési Tudományos Kutatási Programjának támogatásával vizsgálta a közművelődési intézmények és közösségi színterek szerepét a Baranya megyei községek közösségszervezésében. A kutatás strukturált interjúk keretében, rétegzett mintavételi eljárás alapján 29 baranyai falu közművelődési és közösségszervezési gyakorlatát elemezte. A kutatócsoport tagjai Nagypallon, Hosszúhetényben, Nagynyárádon, Mecseknádasdon, Bodán, Hiricsen és Drávaszabolcson tártak fel közművelődési, közösségszervezési jó gyakorlatot. A szerzők a megjelölt hét település közművelődési, közösségszervező szakembereivel lebonyolított, strukturált interjúk keretében vizsgálták a jó gyakorlatok sajátosságait.

A tanulmány 4 keresztmetszetben tárja fel a kutatás során megismert jó gyakorlatok jellemzőit: 1. Finanszírozás - forrásgyűjtés és forráskezelés; 2. Térségi hatások, hálózatosodás a jó gyakorlatokban; 3. A nemzetiségi önkormányzatok szerepe a jó gyakorlatok megvalósításában; 4. A közművelődési szakember személyes és szakmai kompetenciáinak szerepe a jó gyakorlatokban.

A kutatási eredmények alapján a szerzők javaslatokat fogalmaznak meg a községekben működő közművelődési intézmények és közösségi színterek működésének és tevékenységének fejlesztésével kapcsolatosan.

Kulcsszavak: közművelődés; közösségszervezés; jó gyakorlat

\section{Bevezetés}

A PTE BTK HFMI kutatócsoportja 2019 szeptembere és 2020 augusztusa között a Nemzeti Művelődési Intézet Közművelődési Tudományos Kutatási Programjának támogatásával 29 Baranya megyei községben vizsgálta a közművelődési intézmények és közösségi színterek helyi közművelődésben és közösségszervezésben betöltött szerepét. A közművelődési intézmények és közösségi színterek által kínált programok és szolgáltatások típusainak, a programok során alkalmazott közösségszervezési módszereknek, illetve a kommunikációs tevékenység sajátosságainak feltérképezése mellett a kutatócsoport vizsgálta a Baranya megyei községekben működő közművelődési intézmények/ közösségi színterek egyéb intézményekkel és szervezetekkel kialakított kapcsolati hálóját, a kapcsolattartás módjait, a kooperáció jellemzőit, valamint sor került az önkéntesség közművelődésben és közösségszervezésben megvalósuló formáinak feltárására is. A kutatás mindemellett feltérképezte a Baranya megyei községekben működő közművelődési intézmények/ közösségi színterek emberi erőforrásának szakmai kompetenciáit, az intézmények szervezeti működési formáit, finanszírozásának jellemzőit, pályázati tevékenységét és 
egyéb forráskeresési technikáit, valamint a működést nehezítő, akadályozó tényezőket. A kutatás eredményeit a kutatócsoport tagjai magyar és idegennyelvű konferenciaelőadások (Koltai, 2020; Reisz, Koltai \& Kocsis, 2020), valamint írásos publikációk formájában disszeminálta az elmúlt egy évben (Kékesi, 2020; Kocsis, Koltai \& Reisz, 2020; Kocsis, Koltai, Nemes \& Reisz, 2020; Murin, 2020).

A 29 vizsgált település közül a kutatócsoport Nagypallon, Hosszúhetényben, Nagynyárádon, Mecseknádasdon, Bodán, Hiricsen és Drávaszabolcson tárt fel olyan közművelődési, közösségszervezési jó gyakorlatokat, amelyek jó példaként szolgálhatnak a községi közművelődést és közösségszervezést fejleszteni kívánó szakemberek és a falvak vezetői számára. A tanulmány szerzői a fent megjelölt hét település közművelődési, közösségszervező szakembereivel lebonyolított, strukturált interjúk keretében vizsgálta a jó gyakorlatok sajátosságait. Jelen tanulmány a hét vizsgált településen feltárt közművelődési és közösségszervezési jó gyakorlatokat az alábbi négy szempontból vizsgálja: 1 . Finanszírozás - forrásgyűjtés és forráskezelés; 2. Térségi hatások, hálózatosodás a jó gyakorlatokban; 3. A nemzetiségi önkormányzatok szerepe a jó gyakorlatok megvalósításában; 4. A közmüvelődési szakember személyes és szakmai kompetenciáinak szerepe a jó gyakorlatokban.

\section{Kutatási módszerek és a minta}

2019 októberében fókuszcsoportos beszélgetést szerveztünk, melyen a kutatócsoport tagjai mellett a Baranya megyei községekben közösségszervezői, illetve közművelődési tevékenységet végző 10 gyakorlati szakember vett részt. A fókuszcsoportos beszélgetés keretében az alábbi témák feltárására került sor a Baranya megyei falvak közművelődésével, közösségszervezésével kapcsolatosan: a.) szervezeti keretek; b.) a fenntartók, illetve a tevékenységbe bevont humán erőforrás jellemzése; c.) programok áttekintése, illetve a programok megszervezésével és lebonyolításával kapcsolatos nehézségek feltárása; d.) a közművelődésben, közösségszervezésben érintett szakemberek szakmai kapcsolati hálójának áttekintése; e.) anyagi erőforrások. f.) problémák, nehézségek; g.) javaslatok kérése a Baranya megyei falvakban megvalósuló közművelődési- közösségszervezési jó gyakorlatokkal kapcsolatosan.

A fókuszcsoportos beszélgetés tapasztalatai alapján kidolgoztuk a strukturált interjú kérdéssorát (a strukturált interjú kérdéssorát lásd az 1. sz. mellékletben).

2019 novembere és 2020 februárja között a kutatócsoport tagjai rétegzett mintavételi eljárás alapján, strukturált interjút készítettek 29 Baranyai megyei község helyi közmüvelődésben és közösségszervezésben meghatározó szerepet betöltő szakemberével (a mintát lásd a 2. sz. mellékletben). A minta rétegzése a települések lakosságszáma alapján történt meg és az alábbiak szerint csoportosította a Baranya megyei falvakat: a.) Nagyközség (1501-5000 fő) b.) Község (1000-1500 fő) c.) Kisfalu (500-999 fő) d.) Aprófalu (201-500 fő) e.) Törpefalu (200 fő alatti népesség).

Az interjú kérdései feltárták a mintába beválasztott falvak közművelődési intézményeinek, illetve közösségi színtereinek infrastrukturális állapotát, eszközellátottságát, a település közművelődési és közösségi programjait, a szakmai kapcsolatok hálózatát, a települések művelődési- közösségi folyamatainak szervezésében meghatározó szerepet játszó 
humánerőforrás jellemzőit, valamint az anyagi és humánerőforrás gazdálkodásának formáit és a közösségi terek működtetésével kapcsolatban felmerült gondokat és jó gyakorlatokat. Az interjúk zárásaként a közösségi terek mindennapi működésével, fenntartásával kapcsolatosan 25 kérdésre válaszoltak az interjúalanyok ötfokú Likert-skála alapján, így az interjúk elemzése mellett standardizált kérdésekre épülő összehasonlító vizsgálatra is sor kerülhetett a falvak művelődési intézményeinek működéséről, továbbá azok eredményességéről. Az interjúk felvétele mellett, ahol elérhető volt, a kutatók bekérték az interjúalanytól, illetve a helyi önkormányzat illetékes kollégájától az alábbi dokumentumokat: a.) 3 évre visszamenőleg a helyi programnaptárat; b.) a helyi fejlesztési tervet; c.) a közművelődési intézmény alapító okiratát.

A 29 vizsgált település közül a kutatócsoport tagjai hét helyszínen tártak fel olyan közművelődési és/vagy közösségszervezési jó gyakorlatot, amely valamely szempontból követendő példaként határozható meg más községek számára (a mintát lásd a 3. sz. mellékletben). A jó gyakorlatokat felvonultató települések közművelődési és közösségszervező szakembereivel a tanulmány szerzői 2020 áprilisában és májusában strukturált interjúkat bonyolítottak le a helyi jó gyakorlat sajátosságának részletesebb feltárása, valamint a disszemináció és adaptáció lehetőségeinek meghatározása érdekében (az interjúk kérdéssorát lásd a 4. sz. mellékletben).

\section{A Baranya megyei falvak közmúvelődési intézményeinek és közösségi színtereinek müködése - a kutatási eredmények áttekintése}

A mintában szereplő 29 falu közművelődéssel foglalkozó véleményalkotójának értékelése szerint az intézmények működési feltételei és közösségi programjainak eredményei gyenge közepesre értékelhetők. Gyakorlatilag minden település önkormányzata valamilyen módon ellátja feladatát, pontosabban kisebb-nagyobb részt vállal a közösségi élet feltételeinek biztosításában, a pénzügyi keretek megteremtésében. A mélyen elmaradott gazdaság és erodálódott kulturális állapotok konzerválódása jellemzi Baranya megye aprófalvas övezeteit. A falvakban működő művelődési szervezetek változatos elnevezéssel működnek: művelődési ház, integrált közösségi tér, faluház, közösségi ház, közösségi tér, kultúrház, kézműves ház, könyvtár, egyéb elnevezés. A kistelepülések legstabilabb művelődési szervezetei a megmaradt falusi kis (klub) könyvtárak. A kutatás eredményei alapján a változatos közművelődési, közösségszervezési modellek kialakulását a források hiánya motiválta. Az interjúalanyok a szakmai megbecsültség hiányát, az együttműködés nehézségeit, valamint a szakemberhiányt határozták meg leggyakrabban a helyi közművelődéssel, közösségszervezéssel kapcsolatosan legfőbb problémaként.

Néhány kivételtől eltekintve nem található a megyében olyan közművelődési funkciót ellátó intézmény, amely eredetileg is művelődési háznak épült. Az interjúalanyok 41,4\%a településen lévő művelődési infrastruktúrát kimondottan rossznak, 34,5\%-uk közepesnek, illetve 24,1\%-uk jónak értékelte. Ahol alacsony vagy közepes színvonalú a közösségi/közművelődési infrastruktúra, ott a közösségi terek működése alacsony színvonalú. Az infrastruktúra állapota közepes hatást gyakorol a falvak közösségi tevékenységének eredményességére. A kutatás eredményei szerint az egy nagytermes művelődési házak napjainkra lassan funkciójukat veszítik. A mindennapi működéshez szükséges eszközök 
ellátása kevésbé problematikus, mint a művelődési intézmények infrastrukturális helyzete. Ugyanakkor az eszközbeszerzés forrásai bizonytalanok, mert a kistelepüléseknek nincs önerejük a pályázatok beadásához. Sok helyen a Csorba Győző Könyvtár segít az eszközök beszerzésében, a digitális információhordozók korszerűsítésében. A településeknek nyújtott 1,8 millió forint kulturális normatív támogatás az interjúalanyok visszajelzése alapján sem az infrastruktúra, sem a meglévő berendezések, eszközök, informatikai rendszerek korszerűsítésére, sem a havi fütés, víz, villanyáram kifizetésére nem elegendő. Emellett a szakmai végzettséggel rendelkező művelődési szakemberek foglalkoztatását sem fedezi. A külső források felkutatásának és bevonásának az a legelterjedtebb gyakorlata, hogy a kis önkormányzatok vagy körjegyzőségeik térségi, járási szervezetekkel együtt bonyolítják le a közös pályázataikat.

A pályázati rendszerben viszonylag kevés a kizárólag művelődési fejlesztésekre kiírt program, ezért a munkahelyteremtés, településfejlesztés témakörökbe integrált kulturális, oktatási tematikákat jobbára köznevelési intézményekkel, szakemberekkel rendelkező települések érhetik csak el. A megye településeinek hozzávetőlegesen kétharmada kívül marad a forrásgyűjtés e lehetőségétől, mert nem rendelkezik már ilyen feltételekkel.

A helyi szakemberhiány komoly problémát jelent a pályázatok megírásában, ez az egyik legjelentősebb akadálya a források önálló lehívásának. Elterjedt az a foglalkoztatási forma, hogy 8 órában közmunkással, közmunkás bérért, vagy részmunkaidőben foglalkoztatott munkatársra bízzák a művelődés szervezésének feladatát. A falusi közművelődésben tevékenykedők közül kevesen terveznek közösségi vagy művelődésszervezői tanulmányokat, nem tájékozottak a szakma közösségi fórumairól, eseményeiről. A kapcsolati háló összetétele, kiterjedtsége és a közösségi munkában hasznosítható információk eredményességének szintje a kisebb települések felé haladva egyre inkább csökken. A szerény működési feltételek és a szakember hiánya egyben azt is akadályozza, hogy a meglévő szakmai helyi és térségi kapcsolatokat a közösségért tevékenykedők hatékonyan kamatoztathassák. A legszegényebb falvakban országos karitatív szervezetek, illetve egyházak szociális támogató hálózatai próbálják kompenzálni a közművelődés és közösségszervezés hiányosságait. A szakképzetlen, alacsony szakmai kapcsolatrendszerrel, szerény helyi társadalmi és térségi kötődéssel rendelkező interjúalanyok számoltak be a legtöbb nehézségről a helyi közművelődéssel és közösségszervezéssel kapcsolatosan (Kocsis, Koltai, Nemes \& Reisz, 2020; Kocsis, Koltai \& Reisz, 2020).

\section{A közművelődés és közösségszervezés eredményei a jó gyakorlat megva- lósítójaként megjelölt településeken}

Nagynyárádot több generációt megmozgató, tematikusan gazdag kulturális programjai, a helyi hagyományokat megőrző és közvetítő rendezvényei, valamint az önkormányzat, a nemzetiségi önkormányzatok és a helyi nemzetiségi kultúrát közvetítő civil szervezetek példaértékű együttműködése okán határoztuk meg közművelődési és közösségszervezői jó gyakorlatot felvonultató településként. A helyi programok rendkívül széles palettán mozognak, az őstermelőknek borászattal kapcsolatosan szervezett előadásoktól és a helyi falumúzeumban megvalósuló hagyományőrzéstől kezdve, a kékfestő műhelyhez 
kapcsolódó, turisták ezreit a faluba vonzó fesztiválon át a nyugdíjasoknak kínált változatos programokig és a gyerekek számára szervezett nemzetiségi nyári táborig bezárólag. Bár a rendezvények nem minden alkalommal teltházasak, de egyrészről sikerül olyan programokat kínálni, ami érdekli és lelkesíti a helyiek különböző csoportjait, másrészről a változatos tematikájú programok a falu lakosságának teljes spektrumát, valamennyi korosztályt megszólítják. A nagynyárádi közművelődési szakember a saját jó gyakorlata egyik kiemelten fontos elemeként határozta meg a falu identitásának és a lakosok saját identitásának tudatosítását. Tapasztalatai szerint a helyieket érdekli az ősök és falu betelepedésének története, a helytörténet. 2020 elején a közművelődési szakember két nagysikerű, teltházas programot is szervezett a falu, illetve a környék történetével kapcsolatosan. Az első előadás a svábok 18. századi betelepedésével, a második a Mohácsi csata kutatásának legújabb eredményeivel ismertette meg az érdeklődőket. A két előadás témája olyan vonzó volt, hogy nem csak helyi lakosok vettek részt a programokon, de a környékbeli településekről is érkeztek érdeklődők. A programok sikere alapján megállapítható, hogy a saját történelem, a saját identitás alakulásával foglalkozó kezdeményezések kifejezetten érdeklik a helyieket. Különösen a saját családtörténeti vonatkozások feltárásának lehetősége lelkesítette a résztvevőket, például amikor felfedezhették, hogy a bemutatott 18. századi urbáriumban saját családnevük is szerepel, illetve, hogy egy sor, a faluban jelenleg is élő család vezetékneve- német írásmóddal-olvasható a csaknem 250 évvel ezelőtt született dokumentumban. A programok tematikája kapcsán a helyiek érdeklődésének és értékrendjének figyelembevételét, a helyi értékek felismerését, valamint ezen kulturális értékeket közvetítő helyi lakosok programokba való bevonását határozhatjuk meg a jó gyakorlat legfontosabb elemeiként.

„Meg kell őket szólítani az ő hangjukon és az ő értékrendjük szerint. Tudni kell, hogy mi érdekli a helyieket. Meghívhatom ide a Magyar Tudományos Akadémia minden tagozatának a legkiemelkedőbb képviselőjét a mikrobiológiától az űrkutatásig, csak lehet, hogy a nyárádiakat az annyira nem érdekli, hogy melyik aminosav fogja a koronavírust meggyógyítani, mert ezt nem látják át és én sem látom át." (Nagynyárád, 2020. május)

A nagynyárádi közművelődési és közösségszervezési jó gyakorlat másik eleme a helyi hagyományok közvetítésében rejlik. Különösen a helyi sváb, de a horvát kultúrát, hagyományokat is számos program közvetíti és tartja életben sikerrel a településen (pl: Nemzetiségi Nap; Országos Kékfestő Fesztivál; Nemzetiségi Gasztrofesztivál; Német Nemzetiségi Tábor). Továbbá a más településeken is hagyományosan megjelenő falusi rendezvények (pl: bálok; Mikulás ünnepség; Húsvét, stb.) mellett Nagynyárád saját, a mai napig élő hagyományt is követ a Márton-napi búcsúfaállítással.

A Márton-napi búcsút „torkos búcsúnak” („Fresskirmes”) is nevezik. Az elnevezés onnan ered, hogy az őszi mezőgazdasági munkálatok befejeztével a nagynyárádiak a búcsúra vendégeket hívtak és három napig ünnepeltek. Az 1950-es és '60-as években nem tartottak búcsúfaállítást Nagynyárádon. A régi néphagyományt a helyiek 1977-ben elevenítették fel először (Erbné Merkel \& Máy, 2014).

„A búcsúfaállítás itt volt először Nagynyárádon. Lánycsókon próbálkoztak az átvétellel. De az a bensőségesség nem volt ott meg. Ahogy itt mindenki előveszi a sváb ruháját a legapróbbtól a legidősebbig és beöltözik abba, amiben az üknagymama vagy a dédi benne 
volt. Ilyenkor az eredeti ruhákba öltözünk be, ezek féltett kincsek. Ez nincs meg ott. Az, hogy feldíszítenek egy fát, az más. Ennek a hagyománynak az igazi élete itt van Nagynyárádon." (Nagynyárád, 2020. május)

Nagynyárád a rendszerváltást követően a megyében úttörő szerepet játszott a falusi turizmus megindításában és a falusi fesztiválok hagyományának megindításában. Az Országos Kékfestő Fesztivált 1999-ben szervezték meg először, ezzel az egyik első olyan település volt, mely falusi fesztivált rendezett.

Nagynyárádon a jó gyakorlat harmadik eleme a különböző helyi civil szervezetek és önkormányzatok szoros és magas színvonalú kooperációja. A Nagynyárád-Grossnaarad Magyar-Német Baráti Kör, a Német Nemzetiségi Önkormányzat, a Horvát Nemzetiségi Önkormányzat, valamint az önkormányzat folyamatos kommunikációja és szoros együttműködése az alapja számos sikeres kezdeményezésnek.

A helyi közművelődési szakember a település arculatát meghatározó értékek feltárását és disszeminációját, valamint a helyi önkormányzatok és civil szervezetek közötti hatékony kooperációt emelte ki a siker kulcsaként.

„Mindenki abból tud gazdálkodni, ami a sajátja, az a tőke, ami az adott település arculatát meghatározza. Ez nálunk a nemzetiségi hagyományok, a meglévő szellemi és tárgyi örökség. Ugyanígy biztos, hogy minden településnek meg van a maga bája, amit kommunikálhat, eladhat és amire építkezhet. Plusz a kooperáció. Ha tud együtt dolgozni a nagy önkormányzat, a civil szervezetek vezetői és a nemzetiségi önkormányzatok, akkor az mindenképpen egy sikerre vihető történet, az egészen biztos.” (Nagynyárád, 2020. május)

A jó gyakorlat kritériuma ugyanakkor annak megfelelő kommunikálása is, amire interjúalanyunk is felhívta a figyelmet:

„Ahhoz, hogy itt helyben jók legyünk, ahhoz az kell, hogy ezt kivetítsük. Ha kivetíted, akkor már emberekkel is kapcsolatba lépsz. Ehhez az kell, hogy akár a kapcsolati tőkén keresztül megmutasd, hogy mi az, amit tudsz és mi az, amit a település tud. A jó gyakorlathoz mindenképpen az kell, hogy ezt szélesebb kör lássa. Ha csak azok tudják, hogy jó, akik részt vesznek benne, az nem jó gyakorlat." (Nagynyárád, 2020. május)

Hosszúhetényben az aktív pályázati tevékenység, a rentábilis rendezvények szervezésének képessége (Szüreti Fesztivál, ezen belül a Szüreti Bál), a helyi civil szervezetek kezdeményezéseinek támogatása, a 2014-ben az „Év Tájháza” kitüntető címet elnyert Hoszszúhetényi Tájház kultúraközvetítő és múzeumpedagógiai tevékenysége, továbbá a település gazdag programkínálata emelendő ki közművelődési, közösségszervezési jó gyakorlatként. Az önkormányzat, a Nemes János Művelődési Központ és a helyi civil szervezetek egyaránt aktív pályázati tevékenységet folytatnak. A hosszúhetényi programok közül a már több, mint 20 éve minden novemberben Hetényi Hétfő Esték néven meghirdetett, napjainkra hagyománnyá vált ismeretterjesztő előadássorozatot, valamint a település három legnagyobb rendezvényét, a Közösségek Napját, a Talicskaolimpiát és a fiatalokat sikerrel bevonó Szüreti Felvonulást emelhetjük ki közművelődési, közösségszervezési jó gyakorlatként. Interjúalanyunk Hosszúhetényben is a helyi specifikumra való fókuszálást, a beazonosíthatóságot, továbbá a lokálpatriotizmus szerepét emelte ki a jó gyakorlat kritériumaként. 
„Szerintem minden jó gyakorlat egy kicsit lokálpatrióta a közművelődés területén.” (Hosszúhetény, 2020. május)

A közművelődési, közösségszervezési jó gyakorlat megvalósításában a Nemes János Művelődési Központ vezetője hangsúlyozta annak jelentőségét, hogy a településen az iskola, a könyvtár és a közművelődés szerves szövődmény. A szakember mind a közművelődés-közösségszervezés, mind a gazdaságosság szempontjából kifejezetten szerencsésnek tartja azt a körülményt, hogy a művelődési központ irodái az iskola épületében kerültek kialakításra, továbbá, hogy az épületen belül található a könyvtár is.

„Itt vagyunk az iskola épületében, itt van az irodánk. Szerves kapcsolatban vagyunk az iskolával, a gyerekekkel, hiszen ez az épület az, ahova naponta sok száz ember bejön. A szülők is." (Hosszúhetény, 2020. május)

Mecseknádason a helyi adottságokra épülő programokat, a falu helyi értelmiséget helyben tartó képességét és tudástőkéjét, a sváb örökség aktív közvetítését, a helyi lakosság igényeinek figyelembevételét és a magas színvonalú kommunikációt emelhetjük ki a közművelődési-közösségszervezési jó gyakorlat legmeghatározóbb elemeiként. A település gazdag kulturális életében különösen nagy jelentősége van a helyi civil szervezetek nagy számának és aktivitásának, illetve az ezekre épülő önkéntességnek. A helyi néptánccsoport több generációra épül, alapja a családi tradíciók megőrzése. A helyi kulturális életben továbbá fontos szerepe van annak, hogy a művészeti nevelés intézményesült, az ÁMK művészeti iskolával, több tagozattal rendelkezik, így több zenekar rekrutációját a családi hagyományos zenélés mellett az iskola is biztosítja. De van zenélő család, ahol a zenész nagypapa három unokájával rendszeresen bemutatkozik a falu ünnepein, pincebulikon és gyerekbálokon játszanak. Ezek mind helyi értékekre, igényekre, illetve régóta fennálló hagyományokra épülnek. A jó gyakorlatok mögött a tanult önszerveződés, önkénteségen alapuló egyesületi élet vagy baráti csoportok közösségei működnek.

Drávaszabolcsot az önkormányzattal fenntartott jó kapcsolat, a helyi közösség programszervezésbe való aktív bevonása, valamint a gyerekeket sikerrel bevonó ifiklub és meseolvasóklub kapcsán jelölte a kutatócsoport közművelődési és közösségszervezési jó gyakorlatot megvalósító településnek.

Nagypallon a polgármester helyi közművelődéssel és a közösségek támogatásával kapcsolatos elkötelezettsége, a helyi kézműves hagyományok valamennyi korosztályt megcélzó közvetítése, a helyi civil, valamint az országos szervezetekkel és a környékbeli müvelődési csoportokkal való magas szintű kooperáció, továbbá a német nemzetiségi kultúra ápolása kapcsán jelenik meg közművelődési és közösségszervezési jó gyakorlat. A településen minden hónapban ún. csuhé csütörtököt tartanak, ahol kézműves hagyományokat közvetítenek a helyiek és a máshonnan érkező érdeklődők számára, illetve évente 3 csuhétábor is várja a gyerekeket. A helyi kézműves egyesület a Magyar-

Német Baráti Klubbal közösen szervezi meg a Fánksütő versenyt, aminek a keretében sikerül az egész falut megmozgatni, továbbá szintén kooperációban kerül sor a népszerű Kukoricanap lebonyolítására, ahol változatos ételeket készítenek kukoricából.

Bodán a sikeres pályázatírásra épülő forrásgyűjtés, az aktív és kiterjedt önkénteskedés, a családi alapú rendezvények, valamint a környékbeli kistelepülésekkel való hatékony együttműködés határozhatók meg jó gyakorlatként. 
Hiricsen a Máltai Szeretetszolgálat által megvalósított közösségszervezés, ezen belül a hátrányos helyzetű gyerekek számára kínált programok és szolgáltatások, a szülők gyerekneveléssel kapcsolatos ismereteinek bővítése, valamint az egyetemisták önkéntes segítőként való sikeres bevonása indokolta a közművelődési-közösségszervezési jó gyakorlatok közé sorolást. A szervezet keretében például egy gyógypedagógus megtanította a helyi szülőket arra, hogy olvassanak, meséljenek gyermekeiknek, közösen megbeszélték a meséket és feltárták azok nevelésben betöltött fontosságát. A Máltai Szeretetszolgálat emellett kreatív műhelyeket szervez felnőttek és gyerekek számára, valamint havonta egyszer főzőklubot rendeznek a helyiek bevonásával. Interjúalanyunk a jó gyakorlat módszertani sajátosságainak meghatározása kapcsán kiemelte a település szociokulturális jellemzőinek ismeretét és az ahhoz alkalmazkodó programok és szolgáltatások kidolgozását.

\section{Jó gyakorlatok a forrásgyưjtésben és forráskezelésben}

A közművelődési és közösségszervezési jó gyakorlatot megvalósító településeken több esetben találkozhatunk azzal, hogy a helyiek új formát találtak a helyi értékek őrzésére, amelyet a dinamikus közösségek egyben gazdasági tevékenységhez is kötnek. A kézműves hagyományok őrzésére és megújítására kézművesek, fazekasok, borászok táborokat, kiállításokat, képzéseket, külföldi tanulmányutakat szerveznek önerőből vagy rendezvényeik bevételeiből. Nagypallban a helyi közösség megalapítását a szomszéd falu kézműves csoportja saját forrásából finanszírozta.

„Mi úgy tudtunk megalakulni, hogy a várkonyiak ötlete alapján szerveztünk egy több napos tábort tanfolyamokkal és a várkonyiak szalmás csapata a résztvevők által befizetett díjat nekünk adta, így tudtunk megalakulni." (Nagypall, 2020. április)

Jó példák az új művelődési kezdeményezések magánforrású alapítására a nagypalli galéria, a nagynyárádi kékfestőműhely és a hozzá kötődő kékfestő fesztivál, amely önkormányzati támogatással fejlődik évről évre.

Nem elhanyagolható körülmény, hogy az önszerveződésen és önfinanszírozáson alapuló helyi közösségek mindenütt valamilyen, sokszor a múlt távlataiba visszanyúló müvelődési, vagy gazdasági tevékenységre, a helyi társadalom mindennapi életébe beivódott hagyományra építenek. Továbbá minden önszerveződés mögött megtalálható az a személy, család, közösség vagy annak töredéke, akik ezt a mentalitást a közösségi tanulás révén elsajátították. Ez a forrásteremtés az elmúlt évtizedben a helyi civil szerveződések számát jelentősen növelte, valamint a helyi gazdaság és turizmus fejlesztéséhez is erősen kötődik. Vannak olyan települések, ahol a forráshiány pótlásának egyik útját a helyi turizmus élénkítésében látják (Hosszúhetény), vagy ahol ebből a megfontolásból a művelődésszervezést turisztikai szakemberre bízzák (Mecseknádasdon).

A településen kívüli forrásteremtésnek számos formája alakult ki.

Szórványosan ugyan, de külső szervezetektől támogatást, adományt kapnak a települések, például a 300 legszegényebb falu közé tartozó Hiricset a Máltai Szeretetszolgálat segíti.

A külső források között kiemelendő a testvérfalvak által, főként konkrét rendezvényekre, létesítmények felújítására vagy építésére nyújtott támogatások köre. Különösen 
a nemzetiségi falvakban gyakori a testvértelepülések szponzorációja, ami a helyi könyvtárak idegennyelvi állományának bővítésétől kezdve, a lakosságcsere és a háborúk áldozatainak emléket állító köztéri szobrok felállításán és könyvek kiadásán át, tánccsoportok, kórusok, fesztiválok, versenyek pénzügyi vagy tárgyi eszközökkel való támogatásig bezárólag számos helyi közművelődési, közösségi kezdeményezés megvalósítását segíti. Mecseknádasdon a testvértelepülés támogatása kiterjed az egyesületek csereutazásainak finanszírozására is.

Önerős pályázatokból bevont hazai vagy uniós források csak a nagyobb településeken (pl: Hosszúhetény) ismertek, mert az önerő és a projektek előfinanszírozásának biztosítása csak a nagyobb tartalékkal rendelkező, hitelképes fenntartóknak lehetséges.

„Írtunk magunk is pályázatot, tehát az intézmény is írt pályázatot. Plusz az önkormányzat is írt pályázatot. A Talicskaolimpia kísérőprogramjai az NKA-tól is nyertek támogatást. Legutóbb a Csoóri Sándor Programtól." (Hosszúhetény, 2020. május)

Önkormányzat és civil szervezetek együttes pályázatai, főként az önkormányzat és nemzetiségi civil szervezetek, illetve a nemzetiségi önkormányzatok együttes pályázatai az Ormánság cigányok által lakott településein (Drávaszabolcs, Hirics) a hegyháti és a megye keleti sváb falvaiban mindennapos forrásgyűjtési gyakorlattá vált. Az önkormányzat Nagypallban megvásárolt egy parasztházat, amelyet pályázati forrásból felújított, majd a Régi Mesterségeket Felelevenítő Egyesület rendelkezésére bocsátott.

„A polgármester segítségével kaptunk egy felújított sváb házat, a rezsit is fizetik. Korábban ez egy személy öröksége volt, aki Pécsről nem tudta gondozni, így az önkormányzat egy LEADER-programból pénzt pályázott és megvette, felújította az épületet. A polgármesterünk azt mondta, hogy a falu vállalja a karbantartást, fütést, világítást, berendezést, szóval fizetnek mindent, mi töltsük ki élettel." (Nagypall, 2020. április)

Az állandósult forráshiány, valamint a kistelepüléseken a pályázati rendszerben tájékozódni képes pályázatírók hiánya miatt a külső források felkutatásának és bevonásának legelterjedtebb gyakorlata az önkormányzatok térségi, járási szervezetekkel együtt lebonyolított pályázatai. Ezek a kapcsolatok szakmai tartalmukon túl bizalmi kapcsolatok is.

A megye falvainak forrásteremtése és forrásgazdálkodása terén igen sok tartaléka van. Azonban ezek kiaknázásához elsődlegesen hozzáértő szakemberekre lenne szükség. A saját értékek felkutatására és mindezekre stratégiát építő, kapcsolati hálók működtetéséhez tájékozott, jól kommunikáló, a kulturális marketingben jártas szakemberekre lenne szükség. A jó példákkal elöljáró falusi művelődésszervezők a terveket, a forrásgyűjtés lehetőségét is körvonalazták az interjúk során:

„A természeti és szakrális értékek kihasználása szükséges. Olyan természetesnek tűnik ez a szempont, de nem apellálnak rá." (Boda, 2020. május)

„Stratégia kellene, de nem 5 éves, hanem egy-egy éves, amire szellemileg és anyagilag építeni lehetne." (Boda, 2020. május)

„Alapvető lenne, hogy szakmai kompetencia álljon rendelkezésre minden településen. Sajnos az önkormányzatoknál az elvonások miatt nincs forrás, a pályázati keretek lassan kimerülnek, de időlegesen ez működik még és a civil szervezetek is ebből tartják fenn magukat a csekély tagdíjaik mellett. Fontos lenne, hogy minden szakterület jól elkülöníthető pénzügyi fedezettel rendelkezzék. Most nálunk egy kalapból merít a könyvtár, művelődés, 
turizmus, a múzeum és minden tevékenységünk, ami nem hatékony." (Mecseknádasd, 2020. április)

\section{Térségi hatások- hálózatosodás a jó gyakorlatokban}

Baranyában a szegénység térben egyre nagyobb földrajzi területekre terjed ki, a korábban szórványos depressziós kistájakat az elmélyülő szegénység mára nagy összefüggő depressziós térségekké alakította át. A közösségek leépülése elsősorban ott figyelhető meg, ahol nincsenek oktatási intézmények, ahol már nem működik könyvtár sem, illetve helyben nem él olyan szakember, pedagógus, aki a közösségi élet megszervezésére vállalkozna. A helyi társadalom belső hálózatát kiépítő, gondozó személyek hiánya a közösségek hiányában, illetve azok rohamos leépülésében is diagnosztizálható. A helyi háló csomópontjainak eltűnése, az ott élő lakosságot kulturális értelemben is elszegényíti.

A közösségek kialakulásának, fennmaradásának kritikus pontja, hogy a tevékenységüket milyen mértékben tudják elfogadtatni tagjaikkal, valamint a település lakóival. E tekintetben a polgármester, az önkormányzati képviselőtestület elfogadó beállítódása is meghatározónak bizonyul egy adott közösség életében. A kapcsolati tőke igen hasznos a személyes kötődések kialakításában, az aktuális információk és a támogatási csatornák eléréséhez, valamint a biztonságos működtetés alapjainak megteremtéséhez. A kapcsolati tőke meghatározóan nem formalizált személyes kapcsolatokon, viszonosságon és tradicionális együttélésen alapul. Azonban a professzionális közösség-menedzsmentben járatos egyesületek együttműködési megállapodásokkal erősítik meg kapcsolatrendszerüket.

„A településen több közösség is működik, de a meghatározóak a kézműves csoportjaink. A polgármesterünk nagyon elkötelezett. Ha valaki valamit szeretne, annak mellé áll.

Kell egy olyan ember, aki összefogja a kezdeményezéseket, és segíti a feltételeket előteremteni, ez a mi polgármesterünk. Aztán kell valaki, aki érdemben elővezeti és szakmailag gondozza a kezdeményezéseket, foglalkozik az emberekkel és azzal, hogy mi kell. Továbbá kell egy csapat, aki összefog, rendszeresen dolgozik és így együtt el lehet érni a közös célt. Közösségépítés nélkül nem megy. 20 éve indítottam a kézműves csoportunkat, ami ma is jól működik. Nálunk az egyesületi forma bejött, mert sok ember sok ötlete, gondolata működtet bennünket. Azonban a testület nélkül ez nem működne. Egy ilyen kicsi a faluban mindenki mindenről tud, ezért fontos, hogy a falu vezetése segítse a tenni akaró aktívabbakat, illetve támogassa a közösségi életet.” (Nagypall, 2020. április)

„Kell egy olyan polgármester is, aki nem alávág a kulturális szervezőnek vagy a helyi egyesületnek, civil szervezeteknek, hanem támogatja azokat. Aki felismeri, hogy a sikeres kulturális rendezvény rá is jó fényt vet. Egy ilyen kis falunál nincs olyan, hogy ők meg mi." (Nagynyárád, 2020. május)

Az életképes közösségek tagjai közötti viszony bizalmi kapcsolatokon, közös érték és identitásfelfogáson alapul.

A közösségek belső kohéziójának kulcsa, a belső hálózatok kiépülésének módja a folyamatos információcsere, kooperáció és együttesen kialakított, szoros munkamegosztáson alapuló közös tevékenység.

„Akkor lehet sikeres a közművelődés szervezője a településen, ha megtalálja azt a nyelvet, amit a település lakossága beszél. Hogy együtt dolgozzanak, hogy kooperatív legyen a 
dolog. Mert egymagamban kínálhatok én bármit, ha nincsenek meg azok a biztos pontok, akik mellém állnak, és legyen ez egy civil szervezet vagy a nemzetiségi önkormányzat, akkor nem megy." (Nagynyárád, 2020. május)

„A kulcs számomra a jó kommunikáció és az együttműködést értem ez alatt. Hogy folyamatosan beszélünk a polgármesterrel, a másik kulturális szervezettel, a nemzetiségi önkormányzattal. A közművelődési élet szereplőivel - bármilyen kis mértékben is vesznek részt benne-folyamatosan kapcsolatot tartunk, azt kommunikáljuk, hogy mi nyitottak vagyunk az együttműködésre és segítünk, forduljanak hozzánk, de ugyanakkor ezt el is várjuk, tehát egy partneri viszony van. Akkor működik a dolog, amikor senki nem érzi úgy, hogy őt azért hozták, hogy ő legyen a biodíszlet, hanem ha tényleg van szerepe a partnerszervezeteknek is." (Nagynyárád, 2020. május)

„Fontos, hogy az emberek önként és aktívak legyenek. Jók a civil szervezetek is, de az önkormányzathoz kapcsolat kell. Amit eltervezünk, azt megcsináljuk, ehhez különösebb szervezeti háttér nem kell. Sokféle módon lehet az emberekkel együtt dolgozni, de maga a szervezeti forma semmire nem garancia. A személyes kapcsolat a legfontosabb." (Drávaszabolcs, 2020. április)

A falvak közösségi vezetői a helyi társadalmak közösségeivel kiépített jó kapcsolatok jelentőségét, az egymás előnyeit tiszteletben tartó kooperációt, a rendszeres információcserén alapuló belső erős kapcsolatokat és a kicsi helyi hálózatok folyamatos működtetésének jelentőségét hangsúlyozták a jó gyakorlat megvalósításának feltételeiként. Erre számos példát találhattunk, így Nagynyárádon a Magyar-Német Baráti Kör közös programjai, a nagypalli két egyesület közös kézműves táborainak megszervezése, vagy például a mecseknádasdi borászok borversenyei, képzései kapcsán is.

„Sokféle kapcsolatunk van országos szervezetekkel és a környékbeli művelődési csoportokkal Zengővárkonyban a szalmások, a váradi nyugdíjasok, hirdi kórus és mások, mi kölcsönösen tanulunk egymástól és nem zavarunk be például a szalmások dolgaiba, mert mi tartjuk magunkat a csuhé mellett. Tudunk egymásról, egymás rendezvényeire eljárunk, átadjuk egymásnak a híreket, lehetőségeket." (Nagypall, 2020. április)

A nagypalli német és magyar közösségek a falu rendezvényeit együtt bonyolítják le. Ezen túl a környék és a távolabbi települések érdeklődőinek tematikus kézműves tábort szerveznek, alkalmanként több korosztályi vagy szakmai érdeklődő csoport számára.

Hasonló összefogással találkozhatunk a hosszúhetényi üveges fesztivál kapcsán, ami 5 település civil szervezeteinek kezdeményezésére jött létre.

Igen fontos, hogy a térségi szakmai hálózatok kiépítésére jó szakmai referenciák legyenek, valamint hiteles, gyakorlott, szakmai képességeiben biztos szakember építse a településközi kapcsolatokat. A településközi együttműködésnek több formája, változatos tartalma alakult ki, ezeket a működési sajátosságaik alapján organikus közösségi hálózatokként foghatjuk fel, amelyeknek az a sajátosságuk, hogy az együttműködésük hosszú időre nyúlik vissza, továbbá nyelvi, nemzetiségi, illetve vallási azonosságuk köti össze őket. Földrajzi közelségükre a szomszédsági kapcsolat, valamint a néprajzi táji azonosságukból kifolyólag a hasonló életmód, életvitel jellemző. A földrajzi, szakmai, baráti, szomszédsági közelség közös tanulást tesz lehetővé, így nem ritka az a gyakorlat, hogy egyes programo- 
kat más települések is átvesznek, így például a Hirden tartott kézműves táborok a nagypalli gyakorlatot követik, a hosszúhetényi Közösségek Napja című program ötlete pedig a Somogy megyei Lábodról érkezett.

„Több helyre elvittük a nálunk meghonosodott kézművességet és ezzel a tanítási módszereket is. Hirden jártunk a kórusnál és ott tanítottunk csuhézni. Aztán a pécsi német óvoda is hívott minket, mert korábban 24 óvónőt és dadát tanítottunk csuhézni. Most tojásírást tanítottunk volna, de a fertőzés miatt nem lehet Pécsre menni. Mindig azt tanítunk, amire szükség van. Ők meg átveszik a technikákat...Itt a faluban főleg a személyes, emberek közötti beszélgetés útján terjed a hír, de a vezetőinkkel is személyesen értekezünk. A rendezvényeinkről a környéket is tudósítjuk, főleg Pécsváradon a környező iskolákba meghívókat, szórólapokat adunk közre. A váradi tv-be is betesszük, mert a környező kistérségi települések is látják, az egész kistérség eléri ezeket a híreket. Most készül a nagypalli honlap, ott a mi klubjainknak is van linkek, ahol a friss hírek és a rendezvényeink anyagai is megjelennek...A táboraink népszerűek, ezt mi a várkonyiaktól láttuk, ott tanultuk, mi is csináljuk rendszeresen, de elvittük a tábort sok éven át az ukrajnai magyarokhoz is." (Nagypall, 2020. április)

„A Közösségek Napját másutt láttam. A barátom Somogy megyében, Lábodon polgármester, és tőle vettem az ötletet. Nem teljesen úgy csináltuk, mint ők, de a lényege ugyanaz. Ez kb. 20 éve lett bevezetve Hosszúhetényben.” (Hosszúhetény, 2020. május)

„Itt a faluban a meseklub, ifjúsági klub jól működik és a másik két faluba is rendszeresen hívnak. Bostára és Drávapalkonyára szoktam átjárni a gyerekekhez és kreatív foglalkozást, mesét vagy keresztény foglalkozást tartok a gyerekeknek. Bostára úgy megyek, hogy a cigány kisebbségi önkormányzat vezetője hív meg a foglalkozásokra. Nagyon örülnek, ha megyek. Drávapalkonyára a polgármesterasszony hív. Most Anyák napjára készülődünk mind a három helyen." (Drávaszabolcs, 2020. április)

A közösségi hálózatok fontos szereplői a települési és a falun kívülről érkező önkéntes segítők. A kistelepüléseken gyakorlatilag nincs közművelődési szakember. Többnyire részmunkaidős, közmunkás, illetve a szakterületén nagy szeretettel dolgozó segítők mediálják a helyi közösségi életet. Éppen ezért az önkéntesek igen értékes munkát végeznek, szerepük a közösségi hálózatokban megnőtt. Többnyire baráti, vérségi kapcsolatok alapján alakulnak ki a segítő kapcsolatok, amelyek így szorosra füzik a közösségeken belüli és azok közötti emberi kontaktusokat.

A közösségi hálózatok kezdeményezései körében kirajzolódik egy újabb hálózatosodási forma. Térségi szervezetek munkája, ötletei alapján, elsősorban nem szomszédsági kapcsolatokra épülő térségi szervezetek összekapcsolódásáról beszélhetünk. Az alkalmi programok megszervezésére, egyszeri rendezvények lebonyolítására szövetkező falvak a kistérségi vagy a járási intézményi kapcsolatokra, adott közös rendezvény anyagi forrásainak előteremtésére kiírt pályázatok elnyerésére, tehát kimondottan közös forrásteremtésre szerveződnek. Többnyire pénzügyi nehézségekkel küzdő mikrotérségek falvai teremtik meg ebben a formában a falunap megrendezésének pénzügyi hátterét. Sokszor így sikerül előteremteni a gázsit, ekkor a művészek, előadók, együttesek egy napon több faluban is fellépnek. Azonban olyan közös rendezvények is vannak, ahol több falu mutat- 
kozik be egy településen amatőr vagy népi együtteseivel, helyi kézműves termékeivel, továbbá a helyi gazdaságok áruival, gasztronómiai specialitásukkal. A forrásteremtésen kívül olyan településközi együttműködés is kialakult, amikor a közös rendezvény lebonyolítását egy falu művelődésszervezője végzi el, ebben az esetben a térségben hasznosul a kulturális humánerőforrás szaktudása.

A fejlesztési célú kiterjedt társulások közös szervezetet, menedzsmentet, infrastruktúrát működtetnek. Ennek hasznosítását a térség művelődési életében is kamatoztatják. A bodai nukleáris hulladéktelep kialakítását támogató tucatnyi aprófalu szervezete havonta közösen jelentet meg a falvakban egy, az aktuális híreket terjesztő lapot. Ugyanez a szervezet infrastruktúrával és eszközökkel is rendelkezik, így hangosító berendezést és mobil színpadot telepít a kistelepülések rendezvényeire.

„11 település helyi térségi társulatban egy szervezetben működik az atomhulladék-lerakó fejlesztése kapcsán...A 11 falu közös vagyona a rendezvénysátor és a hangosító berendezések. A férjem a gondnok és ő viszi a rendezvények alkalmával az egyes falvakba az infrastruktúrát. Közös még a havi újság, az atomtemető előkészítésével, kutatási adatokkal kapcsolatosan tájékoztatót tartanak minden településen és ez jelenik meg havonta ebben a kistérségi újságban." (Boda, 2020. május)

„A Helyi Értékek Fesztiválját az önkormányzat szervezte és pályázati forrásból finanszíroztuk ezt a közös fesztivált, ahol 7 környékbeli falu mutatta be a helyi értékeit: Kovácshida, Ipacsfa, Gordisa, Alsószentmárton, Drávapalkonya, Matty, Drávaszabolcs. Festőművészek alkotásait, hímzett terítőt, termelői mézet hoztak, aztán jött savanyúság készítő, sajtkészítő, hoztak füstölt árut, a romák a kosárfonást mutatták be, babakészítő, fotográfus mutatkozott még be. Drávaszabolcs falunk a füstöltárújával, mézével, Hegyi Gyula festményével mutatkozott be. Fellépők és sok műsorunk is volt, gasztronómiai érdekességként a romák cigánylecsót főztek. Sorba kirakták az egyes falvak a kirakott asztalokra a helyi értékeiket. Egy hölgyike mikrofonnal körbejárta az asztalokat és bemutatta a helyi termékeket. Kulturális programban a cigányok zenéltek és táncoltak." (Drávaszabolcs, 2020. április)

A legszegényebb falvakra nem mondható el, hogy közösségi hálózatokba szerveződnek, ritka az a törpefalu, ahol közösség működik. Az önszerveződésre képtelen helyi társadalmak körében azonban nyomokban megtalálhatóak a hálózati kapcsolatok. Szórványosan ugyan, de a legszegényebbek segítő kapcsolatokra találnak országos karitatív szervezetek szolgálatai révén, különösön a nagyobb egyházak szociális támogató hálózatát lelni meg a kistelepülések egy részében, így a Máltai Szeretetszolgálat Hiricsen alakított ki segélyhelyet. Az idősek, betegek ellátása mellett oktatással, szabadidőszervezéssel, sport és művelődési programokkal segítik a helyi lakosságot, gyermekek számára játszóházat működtetnek.

\section{A nemzetiségi önkormányzatok szerepe a jó gyakorlatok megvalósításá- ban}

A közművelődési és közösségszervezési jó gyakorlatokat felvonultató települések közül Nagynyárádon, Mecseknádasdon és Nagypallon tölt be a helyi nemzetiségi önkor- 
mányzat kiemelkedően fontos szerepet a kulturális, közösségi élet szervezésében. Jellemző, hogy a közművelődési jó gyakorlatok létrejöttében ezeken a településeken különösen jó partneri viszony jött létre a helyi nemzetiségi és egyéb civil szervezetekkel, illetve a településen működő egyéb (nemzetiségi) önkormányzatokkal. Szoros partneri kapcsolatra, valós, magas szintű együttműködésre, valamint folyamatos kommunikációra és közös tervezésre épülő szervezőmunka alapján valósul meg a helyi programok szervezése ezeken a településeken.

Nagynyárádon különösen aktív a Német Nemzetiségi Önkormányzat a közművelődési és közösségi programok szervezésében, például Márton-nap alkalmából a német tradícióknak megfelelően búcsúfaállítást szervez, 2018 óta pedig nyaranta a helyi sváb tradíciókat és tárgyi emlékeket megismertető Német Nemzetiségi Tábort kínál alsó tagozatos gyerekek számára. A táborban főként olyan, a településről elszármazott gyerekek vesznek részt, akiknek a nagyszülei vagy dédszülei Nagynyárádon élnek.

A Nagynyárád-Grossnaarad Magyar-Német Baráti Kör, a Német Nemzetiségi Önkormányzat, a Horvát Nemzetiségi Önkormányzat, valamint az önkormányzat együttműködése kapcsán a médiában való közös megjelenéstől, a közös pályázatok benyújtásán át, rendezvények partnerségben való megszervezéséig bezárólag említhetjük a jó példákat. A Magyar-Német Baráti Kör és a Német Nemzetiségi Önkormányzat különösen szoros együttműködésben dolgozik, egymás programjainak segítése és támogatása oda-vissza működik, az együttműködés valóban kölcsönösségen alapul, rendszeresen nyújtanak be közös pályázatokat és közös fellépéseket is szerveznek. A Nagynyárádi Kékfestő Fesztivál finanszírozásához a helyi önkormányzat mellett a Német Nemzetiségi Önkormányzat és a Magyar-Német Baráti Kör is hozzájárul. A szervezők minden évben pályázatot nyújtanak be a Baranya Megyei Német Önkormányzathoz is, amely szintén rendszeresen támogatja a rendezvény megvalósítását. A helyi szervezetek valóban szoros együttműködését mutatja az is, hogy a Német Nemzetiségi Önkormányzat tánccsoportja és a Német-Magyar Baráti Kör énekkara nagyon sokszor megy közös busszal, ugyanarra a rendezvényre. Nagynyárádon példaértékű a Német Nemzetiségi Önkormányzat együttműködése a Horvát Nemzetiségi Önkormányzattal, évente egyszer közös Nemzetiségi Napot szerveznek a település egyéb civil szervezeteinek bevonásával, továbbá együttműködésük révén valósul meg a Nemzetiségi Focikupa, illetve a Nemzetiségi Gasztrofesztivál is.

Mecseknádasdon a közösségi és kulturális élet szervezésében aktív szerepet betöltő több nemzetiségi civil szervezet (pl. kórus, táncegyüttes), a Német Nemzetiségi Tájház, valamint a nemzetiségi könyvgyüjteménynek, helytörténeti anyagoknak, klubéletnek és előadásoknak helyet adó ún. Német Ház mellett a Német Nemzetiségi Önkormányzat is különösen fontos szerepet tölt be a nemzetiségi kultúra ápolásában. Példaként említhetjük a vasárnap délutánonként, „Nemzetiségi életünk tegnap és ma” címmel megrendezett előadássorozatot, a 2018 augusztusában átadott tanösvény folyamatos gondozását és aktualizálását, az iskolások számára évente megrendezett szavalóversenyt, a szeptemberi Hősök napi megemlékezést, továbbá az adventi időszakhoz kötődő olyan tevékenységet, mint a betlehem állítás vagy a templom előtti téren, vasárnap esténként szervezett gyertyagyújtás, továbbá a tanulók és más egyesületek részvételével szervezett egyéb programok. 
Nagypallon a Német Nemzetiségi Önkormányzat Farsangi Sváb Bált és szilveszteri futóversenyt szervez, a helyi Magyar-Német Barátság Klub szervezésében pedig Fánksütő verseny és a Karácsonyváró ünnepség várja az érdeklődőket.

\section{A közmúvelődési szakember személyes és szakmai kompetenciáinak sze- repe a jó gyakorlatok megvalósulásában}

A közművelődési jó gyakorlatokat felvonultató Baranya megyei falvak közművelődési szakemberei a falvakban tevékenykedő közművelődési szakember személyével kapcsolatos elvárásként a hitelességet, a település hagyományainak, illetve a lakosság igényeinek és értékrendjének ismeretét, valamint a helyi lakosokkal és szervezetekkel, közösségekkel ápolt intenzív és jó kapcsolat kialakításának képességét említették meg a leggyakrabban.

„A legfontosabb, hogy szót értsen a helyiekkel, hogy tudjon beszélni az emberek nyelvén, jószándékú legyen. Tudjon jól kommunikálni az emberekkel. Tisztelje a helyieket. Fogadják el a helyiek kompetens személynek. Empatikus legyen. A szakmai ismeretek önmagukban nem elegendők, ha nincsenek meg ezek a személyes kompetenciák... Ahhoz, hogy itt helyben jók legyünk, ahhoz az kell, hogy ezt kivetítsük. Ha kivetíted, akkor már emberekkel is kapcsolatba lépsz. Ehhez az kell, hogy akár a kapcsolati tőkén keresztül megmutasd, hogy mi az, amit tudsz és mi az, amit a település tud. A jó gyakorlathoz mindenképpen az kell, hogy ezt szélesebb kör lássa. Ha csak azok tudják, hogy jó, akik részt vesznek benne, az nem jó gyakorlat.” (Nagynyárád, 2020. május)

„Megfelelően fel kell mérni és tisztelni kell az emberek igényeit. Sokat kell beszélgetni velük, számít a véleményük." (Drávaszabolcs, 2020. április)

„Egy elhivatott szakember. Nem is biztos, hogy szakember. De elhivatott. Én ezt emelném ki. Mert a többi mind olyan, ami ettől termékenyül meg. Mert magával tud embereket ragadni." (Hosszúhetény, 2020. május)

„Szerintem kistelepülésen sokkal fontosabb az elfogadottság, mint a szakmai kompetencia. Személyesebb a kapcsolat. Egy városban fontos, hogy aki csinálja, az szakmailag nagyon jól csinálja. Ott is persze a kis közösségeknek van szerepük, de ott azért nagyobbak a dimenziók. A kistelepülésen is jó, ha az az illető valamilyen közösséghez tartozik. Ha nem tartozik sehova, az nem szerencsés. Még Bokor Béla hozott ki csoportot és interjút készített velem a csoport. És akkor gondolkodtam el azon, hogy a népművelőknek -mivel végzősök voltak - ha kikerülnek, mit tanácsolnék. És ezt mondtam, hogy mindenképpen valamely közösségnek minél hamarabb legyenek tagjai. Mert azon keresztül nagyon sok ismeretet tudnak majd szerezni a többi közösségről, hamarabb megismerik a helyi társadalmi viszonyokat." (Hosszúhetény, 2020. május)

„Meg kell tudni mérni, hogy mire van szükség, ehhez jó ítélőképesség kell. Egyedül nem megy, ezért csoportban kell dolgozni és mindenkit meg kell hallgatni." (Hirics, 2020. május)

Több szakember hangsúlyozta a polgármesterrel való jó kapcsolat kialakításának fontosságát is. A falvakban tevékenykedő közművelődési szakemberek kompetenciái kapcsán az interjúba bevont szakemberek többsége hangsúlyozta azt, hogy a falvakban, szem- 
ben a városokkal, nagyobb szerepe van a közművelődési szakember személyes kompetenciáinak, mint a szakmai kompetenciáknak. Továbbá elengedhetetlennek tartják a megkérdezett szakemberek azt, hogy a közösségszervező, közművelődési szakember helyben lakjon.

„A megbízhatóság a legfontosabb. Kell egyetértés és kell valaki, aki ezt hitelesen közvetíti. Kell tudni tárgyalni a falu vezetőivel, de kell érteni ahhoz, hogy a sok eltérő közösségi tag véleményét összehangoljuk, ehhez bizony türelem és emberismeret kell. Jó kapcsolatteremtőnek kell lenni." (Nagypall, 2020. április)

„A személyes kompetenciák ugyanazok. Nagyobb településen a perspektívák szélesebbek. Rétegzettebb a társadalom. Több intézmény van, több civil szervezet. Nyárádon van 5 szervezet. A szakmai kompetenciáknak a nagyobb településeken nagyobb szerepe van." (Nagynyárád, 2020. május)

„A mindenkori kultúrosnak, népművelőnek, kulturális menedzsernek, közösségszervezőnek kell a legfontosabb fogaskeréknek lenni. Neki kellenek a kapcsolatok minden irányban. Hogy rálásson mindenre...Hogy jól ismerjék a helyieket. Maga a személy a lényeg. A személy egyben intézmény ebből a szempontból." (Nagynyárád, 2020. május)

A helyi művelődés-és közösségszervező elvárt személyes kompetenciái közül az alábbiakat jelölték meg a megkérdezett szakemberek a leggyakrabban: kapcsolatteremtő és kommunikációs készség (6), kooperációra-csapatmunkára való készség (3), szervezőkészség (3), megbízhatóság (3), hitelesség (3), szociális érzékenység (2). Az alábbi kritériumokat említették meg az interjúalanyok a fentiek mellett: karizmatikus, alázatos, rugalmas, elhivatott, kompromisszumra képes, türelmes, kitartó, nyitott.

„Ilyen kis településen a személyes ismeretség a lényeg, nem a módszertan. Hogy normális, hiteles ember legyen és értelmes célokat tűzzön ki. A személyes kompetencián múlik, nem a szakmai kompetencián." (Nagynyárád, 2020. május)

A szakmai kompetenciák közül az alábbiakat tartják legfontosabbnak a megkérdezettek: helyismeret (5), digitális kompetenciák (2), hálózatépítési készség, forrásteremtésre való képesség, mediáció- konfliktuskezelés, szakmai képzettség.

„Aki elvállalja ezt a szerepkört és jó gyakorlatot akar, annak ismernie kell a falut, a lakosságot, hogy kik laknak itt. Ismernie kell a helyieket, a potenciális közönséget/réteget. Ha ismeretlenül odamegy, akkor ez nem fog működni. Ott legyen otthon." (Nagynyárád, 2020. május)

„Itt a helyi társadalom ismerete, a helyi identitással való azonosulás, jó közösségi önismeret igen fontos, mert csak hiteles és helyben jól tájékozódó, helyben elfogadott nem szakember tud önszerveződésben, önkéntesek együttműködésével cselekedni." (Mecseknádasd, 2020. április)

„Értenie kell a forrásteremtéshez, a rendszerben való gondolkodáshoz és igen lényeges, hogy térben is hálózatosodásra törekedjen. Ehhez nemcsak a térbeli, hanem a digitális kompetenciák is kellenek." (Mecseknádasd, 2020. április)

A válaszadók közül többen hangsúlyozták annak fontosságát is, hogy a helyi közművelődési, közösségszervező szakembernek elfogadottnak kell lennie a közösség tagjai szemében. 
„A hitelesség a lényeg. Az az ember, aki szervezi, annak hitelesnek kell lennie azok előtt, akikkel akar valamit szervezni és azok előtt, akiknek akar valamit szervezni." (Nagynyárád, 2020. május)

\section{Konklúzió, javaslatok}

Szoros térségi- szomszédsági kapcsolatok, illetve szakmai együttműködések, valamint nyomokban a falvak, szervezetek közötti kapcsolatok ott épülnek ki, ahol részben, vagy egészében működnek a köznevelési intézmények, a belső kapcsolatok és az egyesületi élet aktív, továbbá a helybelieket és a környező települések lakóit is invitáló, közösségi találkozásra alkalmas rendezvényeket tartanak. A közművelődési jó gyakorlatok sikerességét nagy mértékben az határozza meg, hogy mennyire tud a program a helyi igényekre reflektálni.

A kutatás eredményei alapján községi közművelődési és közösségszervezési jó gyakorlatok megvalósításához az alábbiakat javasoljuk:

1. a helyi lakosság igényei alapján kidolgozott, több generációt megmozgató, tematikusan gazdag, a helyi hagyományokat és specifikumokat érvényesítő kulturális programok szervezése;

2. a helyi önkormányzatok és civil szervezetek magas szintű kooperációja és folyamatos kommunikációja;

3. a településen túlnyúló szakmai kapcsolati hálók kialakítására és működtetésére, a helyi civil szervezetekkel és önkormányzatokkal való együttműködésre, valamint a helyi közösség bevonására és önkéntesek aktivizálására képes, továbbá a pályázatírásban és forrásgazdálkodásban kompetens, jó kommunikációs és kapcsolatteremtő képességgel és helyismerettel rendelkező művelődés-és közösségszervező foglalkoztatása;

4. A baranyai elaprózott településszerkezetet egyben elszegényedett lakosság, valamint szűk anyagi, szellemi és humánerőforrású intézmények jellemzik. A hiányok halmozódása, azok közösségi hatásai elsősorban képzett szakemberek alkalmazásával, illetve rendszerszerűen átgondolt továbbképzésekkel mérsékelhetők. Javasoljuk, hogy a pozitív tapasztalatok átadására, a tudástranszfer megszervezésére térségi szinten koordinált fórum biztosítsa a kistelepülések közösségi életének építését. A fórum alkalmas lehet a közös forrásallokáció megszervezésére, valamint a jó gyakorlatok terjesztésére.

A jó gyakorlatok adaptálása kapcsán mindenképpen figyelembe kell venni a helyi sajátosságokat. Egy az egyben nem lehet átvenni egy jó gyakorlatot, a rendelkezésre álló helyi kondíciók (infrastruktúra, eszközállomány, humánerőforrás, stb.), illetve a település helyi specifikumainak figyelembevétele mindenképpen szükséges. Sőt, a közművelődési jó gyakorlatokat megvalósító interjúalanyaink véleménye szerint nem is minden konkrét jó gyakorlatot lehet adaptálni, pont azok hely- vagy közösségspecifikus jellege okán. Ugyanakkor mindenképpen szükség lenne a helyi közművelődési, közösségszervezési jó gyakorlatokat rögzítő és bemutató esetismertetők közzétételére, adaptálhatóságuk elősegítése, a szakmai kapcsolati hálók erősítése, továbbá a kistelepüléseken művelődés -és közösségszervezői feladatokat ellátó személyek szakmai elszigeteltségének és információhiányának csökkentése, illetve módszertani fejlődésének támogatása érdekében. 
Az esetismertetőknek az adott sikeres program valamennyi aspektusát le kellene írnia az időkiválasztástól, valamint az infrastrukturális és személyi feltételektől kezdve a jegyértékesítésen, technikai információkon, a partnerek bevonásának módján és a rendezvény biztosításának (mentőszolgálat, security, stb.) kérdésein át a terjesztéssel, marketinggel kapcsolatos információkig bezárólag. A jó gyakorlatok megvalósítása során felmerült nehézségek, illetve a szervezés, tervezés, kivitelezés kapcsán esetlegesen elkövetett hibák feltárása és megosztása szintén nagy segítséget jelentene a programot adaptálni kívánó művelődés-és közösségszervezők számára.

A községi jó gyakorlatok publikációk formájában való közzététele mellett érdemes lenne továbbá olyan tanulmányutakat szervezni a községi közművelődéssel és közösségszervezéssel foglalkozók számára, ahol lehetőség nyílna a közművelődési, közösségszervezési jó gyakorlatokat felvonultató települések helyi vezetőivel, a jó gyakorlatot kitaláló, illetve megvalósító személlyel vagy akár a résztvevőkkel szervezett személyes beszélgetésre, továbbá a kapcsolati háló erősítésére. A konkrét program és az alkalmazott közösségszervezési módszerek feltárása mellett javasoljuk a rendezvénnyel kapcsolatos promóció megismertetését is (pl. plakátok, meghívók bemutatása, stb.).

\section{Irodalomjegyzék}

Erbné Merkel, Cs., \& Máy, P. (2014). Unser Erbe- Örökségünk. Nagynyárádi Német Nemzetiségi Önkormányzat.

Kékesi, E. (2020). Falunapok, fesztiválok, művészeti és egyéb táborok a Baranya megyei falvakban. Tudásmenedzsment, 21 (különszám), 256-264.

Kocsis, M., Koltai, Zs., Nemes, K., \& Reisz, T. (2020). Infrastruktúra, eszközellátottság és finanszírozás a Baranya megyei falvak közművelődésében. Kézirat. Kulturális Szemle, megjelenés alatt.

Kocsis, M., Koltai, Zs., \& Reisz, T. (2020). Best Practices and Challenges of the Cultural Institutions in Baranya County Villages. Kézirat. Kulturális Szemle, megjelenés alatt.

Koltai, Zs. (2020): Cultural Life and Community Building in Baranya County Villages. Abstract. / Közművelődés és közösségszervezés Baranya megye falvaiban. Absztrakt. In Csuka, D. (szerk.), Tanulás - Tudás Innováció a felsőoktatásban. Reflektorfényben az innováció kihívásai/ Learning - Knowledge - Innovation in Higher Education. Focusing on the Challenges of Innovation. 16. MELLearN Lifelong Learning Konferencia, Absztraktkötet/16th Conference of MELLearN - Hungarian Universities' Lifelong Learning Network, Collection of Abstracts. MELLearN Egyesület.

Murin, K. (2020). A „Jó gyakorlatok” helye a közösségfejlesztésben. Tudásmenedzsment, 21 (különszám), 265-277.

Reisz, T., Koltai, Zs., \& Kocsis, M. (2020). A közművelődés helyzete a Baranya megyei községekben. Absztrakt. In Juhász, E., \& Márkus, E. (szerk.), Hálózatok a müvelődés és felnőttképzés világában: Absztraktkötet. Tudományos Konferencia és Szakmai Találkozó Durkó Mátyás emlékére. Debreceni Egyetem, Bölcsészettudományi Kar.

\section{Szóbeli adatközlők:}

Strukturált interjú 29 Baranya megyei falu közművelődési szakemberével, 2019. november-2020. február (a mintát lásd a 2. sz. mellékletben)

Strukturált interjú a közművelődési, közösségszervezési jó gyakorlatokat megvalósító 7 Baranya megyei falu közművelődési szakemberével, 2020. április-május. (a mintát lásd a 3. sz. mellékletben)

Egyéb dokumentumok:

Helyi közművelődési intézmények alapító okirata

Helyi fejlesztési tervek, önkormányzati rendeletek a 29 vizsgált településről 


\section{Mellékletek}

1. sz. melléklet: A strukturált interjú kérdéssora - „A közművelődési intézmények és közösségi színterek szerepe a Baranya megyei községek közösségfejlesztésében” című kutatás, Nemzeti Művelődési Intézet „Közművelődési Ösztöndíj Kutatócsoportok számára”, 2019-2020, PTE BTK HFMI kutatócsoport

Baranyai falvak közmúvelődési, közösségi terei működésének vizsgálata

1. Név:

2. Település neve:

3. Lakosságszám (fö):

4. Intézmény hivatalos neve:

5. Az intézmény címe, e-mail, telefonszám:

6. Honlap elérhetősége:

7. A helyiek miként nevezik az intézményt?

8. Kérjük, mutassa be önmagát!

9. Kérjük, mutassa be a településén lévő közmứvelődési intézményeket, szervezeteket, illetve a településen múködő múvelődési folyamatokat/aktivitásokat! Milyen mûvelődési folyamatok/aktivitások voltak a településen az elmúlt 5 évben? Kérjük, rendszerezze, illetve jellemezze intézménye programjait!

10. Kérjük, jellemezze a helyi közművelődési intézmény vagy közmúvelődési tevékenység infrastrukturális feltételeit és szervezeti kereteit!

11. Kérjük, ismertesse és jellemezze az ellátott közmüvelődési tevékenység pénzügyi gazdálkodási hátterét, illetve fenntartóját!

12. Kérjük, jellemezze munkatársi gárdáját! 13. Kérjük, jellemezze az intézményhasználók körét!

14. A közmúvelődési alapszolgáltatások közül melyek teljesülnek a településen? Milyen formában? Ön szerint még mire lenne szükség a településen? Miért?

15. Kérjük, jellemezze intézménye és feladatellátási körében végzett egyéni kommunikációs gyakorlatát, illetve intézménye és a személyes szakmai kapcsolati hálóját!

16. Kérjük, sorolja fel és jellemezze intézménye eredményeit!

17. Kérjük, sorolja fel és jellemezze intézménye működési problémáit!

18. Kérjük, hogy ismertesse az intézményének múködésével kapcsolatos fejlesztési terveket!

19. Kérjük, hogy jellemezze azokat a programokat és szolgáltatásokat, amelyeket saját működési repertoárjából - úgynevezett jó gyakorlatként - mások figyelmébe tudna ajánlani! Ezeket miért nevezné jó gyakorlatnak? (Mitől jó gyakorlat a jó gyakorlat?) Ismer-e más intézményi gyakorlatból adaptálható jó gyakorlatokat? Mire lenne ez megoldás az Ön intézményében?

20. Kérjük, mondja el, hogy a kistelepülések közművelődésének, közösségszervezésének fejlesztésével kapcsolatban milyen rendszerszintű javaslatai lennének! 
21. Mi az a gond, probléma, amely Önt napjainkban foglalkoztatja?

22. Ön szerint ki az, aki a település közművelődéséről további információkat tudna nyújtani a kutatás számára?

Kérjük, értékelje a helyi közművelődési intézmény (ek) működési feltételeit 1-5-ig terjedő pontokkal! A legrosszabb intézményi feltételek 1, a legjobb érték 5 pontot kapjon!

\begin{tabular}{|l|l|l|l|l}
1 & 2 & 3 & 4 & 5
\end{tabular}

Kérjük, értékelje a helyi közművelődési intézmény (ek) szervezeti kereteit az optimális működés szempontjából 1-5-ig terjedő pontokkal! A legrosszabb szervezeti feltétel 1 , a legjobb érték 5 pontot kapjon!

\begin{tabular}{|l|l|l|l|l|}
\hline 1 & 2 & 3 & 4 & 5 \\
\hline
\end{tabular}

Kérjük, értékelje a közművelődési intézmény és a fenntartó közötti együttműködést 1-5-ig terjedő pontokkal! A legrosszabb feltétel 1, a legjobb érték 5 pontot kapjon!

\begin{tabular}{|l|l|l|l|l|}
\hline 1 & 2 & 3 & 4 & 5 \\
\hline
\end{tabular}

Kérjük, értékelje közművelődési munkáját az optimális mưködés szempontjából 15-ig terjedő pontokkal! A legrosszabb vezetői feltételek 1, a legjobb érték 5 pontot kapjon!

\begin{tabular}{|l|l|l|l|l|}
\hline 1 & 2 & 3 & 4 & 5 \\
\hline
\end{tabular}

Kérjük, értékelje jövedelmét a megélhetéséhez szükséges elvárása szerint 1-5-ig terjedő pontokkal! A legrosszabb jövedelmi lehetősége 1 pont, a legjobb értéke 5 pont.

\begin{tabular}{|l|l|l|l|l|}
\hline 1 & 2 & 3 & 4 & 5 \\
\hline
\end{tabular}

Kérjük, értékelje a helyi közmúvelődésben szerepet játszó munkatársak szakmai együttmüködését 1-5-ig terjedő pontokkal! A legrosszabb működés 1, a legjobb érték 5 pontot kapjon!

\begin{tabular}{|c|c|c|c|c|}
\hline 1 & 2 & 3 & 4 & 5 \\
\hline
\end{tabular}

Kérjük, jelölje, hogy a közmüvelődési tevékenységéhez áll-e rendelkezésre infrastruktúra? Az infrastruktúra hiánya 1, a teljes ellátás 5 pontot kapjon!

\begin{tabular}{|l|l|l|l|l|}
\hline 1 & 2 & 3 & 4 & 5 \\
\hline
\end{tabular}

Kérjük, értékelje a helyi közművelődési intézmény működéséhez szükséges infrastruktúra adottságait, állapotát, minőségét 1-5-ig terjedő pontokkal! A legrosszabb infrastruktúra esetén 1 , a legoptimálisabb esetén 5 pontot adjon!

\begin{tabular}{|l|l|l|l|l|}
\hline 1 & 2 & 3 & 4 & 5 \\
\hline
\end{tabular}

Kérjük, értékelje a helyi közmúvelődési intézmény múködéséhez szükséges infrastruktúra adottságait az Önökéhez hasonló nagyságú Baranya megyei településekhez viszonyítva 1-5-ig terjedő pontokkal! A legrosszabb érték esetén 1, a legjobb infrastruktúra esetén 5 pontot adjon!

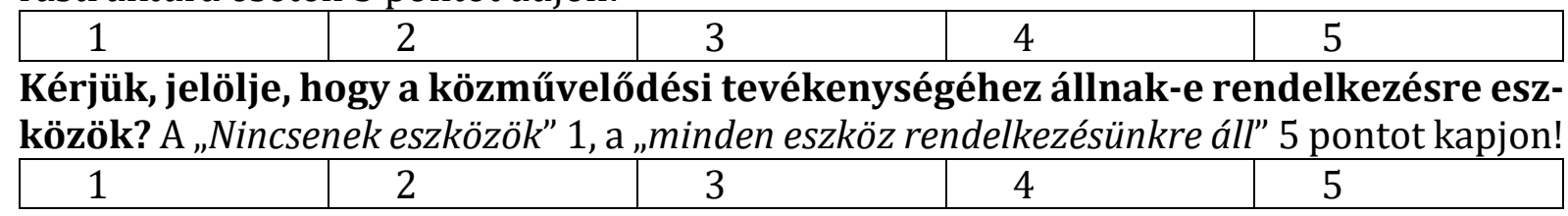


Kérjük, értékelje a helyi közművelődési intézmény eszköz-ellátottságának minőségét 1-5-ig terjedő pontokkal! A legrosszabb eszköz-ellátottság esetén 1, a legoptimálisabb esetén 5 pontot adjon!

\begin{tabular}{|l|l|l|l|l|}
\hline 1 & 2 & 3 & 4 & 5 \\
\hline
\end{tabular}

Kérjük, értékelje a helyi közművelődési intézmény eszköz-ellátottságát az Önökéhez hasonló nagyságú Baranya településekhez viszonyítva 1-5-ig terjedő pontokkal! A rossznak ítélt eszköz-ellátottság esetén 1, optimális esetben 5 pontot adjon!

\begin{tabular}{|l|l|l|l|l|}
\hline 1 & 2 & 3 & 4 & 5 \\
\hline
\end{tabular}

Kérjük, értékelje a helyi közmúvelődési intézmény anyagi erőforrásait 1-5-ig terjedő pontokkal! A legrosszabb forrásgazdálkodási lehetőség 1, a legjobb érték 5 pontot kapjon!

\begin{tabular}{|l|l|l|l|l|}
\hline 1 & 2 & 3 & 4 & 5 \\
\hline
\end{tabular}

Kérjük, értékelje a helyi közművelődési intézmény programjait 1-5-ig terjedő pontokkal aszerint, hogy azokkal mennyire elégedett a helyi lakosság! A legrosszabb 1 , a legjobb érték 5 pontot kapjon!

\begin{tabular}{|l|l|l|l|l|}
\hline 1 & 2 & 3 & 4 & 5 \\
\hline
\end{tabular}

Kérjük, értékelje a helyi közművelődési intézmény programjait 1-5-ig terjedő pontokkal aszerint, hogy mekkora a helyi lakosság részvétele! A legrosszabb 1, a legjobb érték 5 pontot kapjon!

\begin{tabular}{|l|l|l|l|l|}
\hline 1 & 2 & 3 & 4 & 5 \\
\hline
\end{tabular}

Kérjük, értékelje a helyi közművelődési intézmény szolgáltatásait a lakosság elégedettsége szempontjából 1-5-ig terjedő pontokkal! A legrosszabb 1, a legjobb érték 5 pontot kapjon!

\begin{tabular}{|l|l|l|l|l|}
\hline 1 & 2 & 3 & 4 & 5 \\
\hline
\end{tabular}

Kérjük, értékelje helyi közművelődési intézmény kommunikációját a naprakészség szempontjából 1-5-ig terjedő pontokkal! A leggyengébbre értékelés 1, a legjobb 5 pontot kapjon!

\begin{tabular}{|l|l|l|l|l|}
\hline 1 & 2 & 3 & 4 & 5 \\
\hline
\end{tabular}

Kérjük, értékelje a helyi közművelődési intézmény kommunikációját az eredményesség szempontjából 1-5-ig terjedő pontokkal! Az eredménytelen 1, a mindig sikeres 5 pontot kapjon!

\begin{tabular}{|l|l|l|l|l|}
\hline 1 & 2 & 3 & 4 & 5 \\
\hline
\end{tabular}

Kérjük, értékelje a szakmai kapcsolati hálójának összetételét, sokoldalúságát 1-5ig terjedő pontokkal! Az egyelőre még ki nem alakult 1, a sokoldalú 5 pontot kapjon!

\begin{tabular}{|l|l|l|l|c|}
\hline 1 & 2 & 3 & 4 & 5 \\
\hline
\end{tabular}

Kérjük, értékelje kapcsolati hálójának eredményességét, hatékonyságát 1-5-ig terjedő pontokkal! Az eredménytelen 1, a mindig eredményes 5 pontot kapjon!

\begin{tabular}{|l|l|l|l|l|}
\hline 1 & 2 & 3 & 4 & 5 \\
\hline
\end{tabular}


Kérjük, értékelje helyi közmúvelődési intézmény működési eredményeit a müködési lehetőségekhez viszonyítva 1-5-ig terjedő pontokkal! A lehetőségeihez képest nagyon rossz eredmények 1 , a kiváló eredmények 5 pontot kapjanak!

\begin{tabular}{|l|l|l|l|l|}
\hline 1 & 2 & 3 & 4 & 5 \\
\hline
\end{tabular}

Kérjük, értékelje helyi közművelődési intézmény működési eredményeit a lakosság igényeinek kielégítése szempontjából 1-5-ig terjedő pontokkal! A lakossági elégedetlenség 1 , a teljes megelégedettség 5 pontot kapjon!

\begin{tabular}{|l|l|l|l|l|}
\hline 1 & 2 & 3 & 4 & 5 \\
\hline
\end{tabular}

Kérjük, értékelje a helyi közművelődési intézmény mưködési eredményeit az Önéhez hasonló nagyságú Baranya megyei települések eredményeihez viszonyítva 1-5ig terjedő pontokkal! A hasonló nagyságú településekhez viszonyítva nagyon rossz eredmények 1, a kiváló eredmények 5 pontot kapjanak!

\begin{tabular}{|l|l|l|l|l|}
\hline 1 & 2 & 3 & 4 & 5 \\
\hline
\end{tabular}

Kérjük, értékelje 1-5-ig terjedő pontokkal, hogy a helyi közművelődési intézmény eredményességét a múködési problémák mennyire befolyásolják! A „nem befolyásolják” 1, a „nagymértékben befolyásolják" 5 pontot kapjon!

\begin{tabular}{|l|l|l|l|l|}
\hline 1 & 2 & 3 & 4 & 5 \\
\hline
\end{tabular}

Kérjük értékelje komfortérzetét jelenlegi munkakörében?

Az „Egyáltalán nem érzem jól magam benne” 1, a „nagyon jól érzem magam benne” 5 pontot kapjon!

\begin{tabular}{|l|l|l|l|l|}
\hline 1 & 2 & 3 & 4 & 5 \\
\hline
\end{tabular}

2. sz. melléklet: Minta - strukturált interjú, „A közművelődési intézmények és közösségi színterek szerepe a Baranya megyei községek közösségfejlesztésében" című kutatás, Nemzeti Múvelődési Intézet „Közművelődési Ösztöndíj Kutatócsoportok számára", 2019-2020, PTE BTK HFMI kutatócsoport

1. Abaliget

2. Beremend

3. Boda

4. Bosta

5. Drávacsehi

6. Drávaszabolcs

7. Feked

8. Felsőegerszeg

9. Hirics

10. Hosszúhetény

11. Kétújfalu

12. Kisbeszterce

13. Kisdobsza

14. Kővágótöttös 
15. Magyartelek

16. Márfa

17. Mecseknádasd

18. Nagynyárád

19. Nagypall

20. Ózdfalu

21. Patapoklosi

22. Sárok

23. Sumony

24. Szajk

25. Szulimán

26. Tengeri

27. Velény

28. Véménd

29. Zengővárkony

3. sz. melléklet: Közmúvelődési, közösségszervezési jó gyakorlatokat megvalósító települések listája, „A közmưvelődési intézmények és közösségi színterek szerepe a Baranya megyei községek közösségfejlesztésében" című kutatás, Nemzeti Művelődési Intézet „Közművelődési Ösztöndíj Kutatócsoportok számára”, 2019-2020, PTE BTK HFMI kutatócsoport

1. Boda

2. Drávaszabolcs

3. Hirics

4. Hosszúhetény

5. Mecseknádasd

6. Nagynyárád

7. Nagypall

4. sz. melléklet: A jó gyakorlatok sajátosságait feltáró strukturált interjú kérdéssora, „A közmúvelődési intézmények és közösségi színterek szerepe a Baranya megyei községek közösségfejlesztésében" című kutatás, Nemzeti Művelődési Intézet „Közmúvelődési Ösztöndíj Kutatócsoportok számára”, 2019-2020, PTE BTK HFMI kutatócsoport

\section{Konkrét jó gyakorlatok ismertetése}

1. Ön jó gyakorlatként határozná-e meg a településen megvalósított közművelődési/ közösségszervezői gyakorlatot/ folyamatokat? Ha igen, miért? Ha nem, miért nem?

2. Ön szerint mi teszi jó gyakorlattá a közművelődési / közösségszervezői jó gyakorlatot? Mitől nevezhetünk valamit jó gyakorlatnak?

3. Kérem határozzon meg maximum 3 programot / folyamatot, melyet Ön jó gyakorlatként értékel a településen! A 2. pontban említett tényezők közül ezekben melyek érvényesülnek? 
4. Van-e olyan személy, szervezet vagy intézmény a településen, akinek/ melynek szerepét a jó gyakorlat megvalósításában kiemelné? Miben és mennyiben járult hozzá a sikerhez?

5. Az Ön véleménye szerint milyen szervezeti sajátosságai vannak egy jó gyakorlatnak?

6. Ön szerint van-e szerepe a helyi közművelődési szakember személyes/ szakmai kompetenciáinak a jó gyakorlat megvalósulásában?

7. Véleménye szerint milyen személyes és szakmai kompetenciákkal kell rendelkeznie a közművelődési/ közösségszervező szakembernek a jó gyakorlatok megvalósításához?

8. Ön szerint milyen személyes és szakmai kompetenciákkal kell rendelkeznie egy kistelepülésen működő közművelődési / közösségszervező szakembernek? Van-e különbség e kompetenciákban a település mérete szerint?

9. Kérem, hogy mutassa be az ismertetett gyakorlatok finanszírozási, pénzügyi és forráskezelési eljárásainak formáit!

10. Ön szerint milyen finanszírozási forma lenne ideális közművelődési jó gyakorlatok megvalósításához?

11. Vannak-e módszertani sajátosságai a jó gyakorlatoknak?

12. Ön szerint milyen módszereket érdemes alkalmazni közművelődési jó gyakorlatok megvalósításához?

13. Mi az, amit az ismertetett jó gyakorlatból modellként javasolna más települések számára?

14. Az Ön véleménye szerint milyen feltételei/ kockázatai vannak az Ön által megvalósított jó gyakorlat más településen való megvalósításának?

15. Tud-e arról, hogy az Ön településén megvalósult jó gyakorlat valamely elemét más település átvette volna? Amennyiben igen, milyen módon történt a jó gyakorlat megismertetése, illetve átvétele?

16. Az Ön véleménye szerint miként mérhető a közművelődési / közösségszervezői jó gyakorlat eredményessége/ hatékonysága?

\section{A jó gyakorlatok mindennapi terjesztését segítő, javasolható "jó gyakorlatok"}

17. Milyen javaslatai vannak a jó gyakorlatok terjesztésének szervezeti formáival kapcsolatosan?

18. Milyen javaslatai vannak a jó gyakorlatok terjesztésének kommunikációs formáival kapcsolatosan?

\section{A sikeres, pozitív múvelődési gyakorlatok kutatásának módszertani lehetőségei - az esetismertetések szempontjai}

19. Milyen módszerekkel kutatná és rögzítené a kistelepülések művelődési folyamatait segítő pozitív művelődési gyakorlatokat?

20. Milyen konkrét szempontok mentén mutatná be, írná le a sikeres, pozitív művelődési tapasztalatokat?

21. Kérjük, hogy tegyen javaslatot a jó gyakorlatokat rögzítő esetismertetők, azok adaptálhatóságát segítő megoldásokra! 
5. sz. melléklet: A PTE BTK HFMI kutatócsoport tagjai - „A közművelődési intézmények és közösségi színterek szerepe a Baranya megyei községek közösségfejlesztésében” című kutatás, Nemzeti Mûvelődési Intézet „Közművelődési Ösztöndíj Kutatócsoportok számára", 2019-2020

Kékesi Eszter

Kocsis Mihály PhD

Koltai Zsuzsa PhD

Murin Kata

Nemes Krisztina

Pásztor Andrea

Poór Gabriella

Reisz Terézia PhD, habil andragógus, kulturális mediátor, közművelődési szakember címzetes egyetemi tanár, PTE BTK HFMI kutatásvezető, adjunktus, PTE BTK HFMI közösségszervezés szakos hallgató, PTE BTK HFMI megyei igazgató, NMI Baranya Megyei Igazgatósága muzeológus, Janus Pannonius Múzeum kulturális mediáció szakos hallgató, PTE BTK HFMI egyetemi docens, PTE BTK HFMI 